DOI

\title{
РОЛЬ РОЗРАХУНКОВИХ ЗАДАЧ ПРИ ВИВЧЕННІ АНАЛІТИЧНОЇ ХІМІЇ У ФАРМАЦЕВТИЧНІЙ ОСВІТІ
}

\author{
І. Б. Івануса, М. М. Михалків, А. Є. Демид \\ ДВНЗ “Тернопільський державний медичний університет імені I. Я. Горбачевського \\ МОЗ України”
}

\section{THE ROLE OF CALCULATION TASKS AT STUDYING OF ANALYTICAL CHEMISTRY IN PHARMACEUTICAL EDUCATION}

\author{
I. B. Ivanusa, M. M. Mykhalkiv, A. Ye. Demyd \\ SHEI “Ternopil State Medical University by I. Ya. Horbachevsky of MPH of Ukraine”
}

\begin{abstract}
У статті наведено роль та необхідність використання розрахункових задач при вивченні аналітичної хімії студентами фармацевтичного факультету у ДВНЗ “Тернопільський державний медичний університет імені І. Я. Горбачевського МОЗ України”.
\end{abstract}

The article describes the role and necessarily usage the calculation tasks at studying of analytical chemistry on Pharmaceutical Faculty in SHEI “Ternopil State Medical University by I. Ya. Horbachevsky of MPH of Ukraine”.

Кем бы вы ни стали, вы все равно будете заниматься аналитикой. Д-р хим. наук, проф. Л. Н. Москвин

Вступ. Розрахункові задачі посідають особливе місце при вивченні аналітичної хімії. Систематичне їх розв’язування сприяє свідомому засвоєнню хімічних знань, формуванню логічного мислення, розвитку розумової діяльності, навчає практичного використання набутих теоретичних знань. Введення задач у навчальний процес дає змогу реалізувати такі дидактичні принципи навчання, як забезпечення самостійності й активності студентів, досягнення єдності знань і вмінь.

Розрахункові задачі можна використовувати на всіх етапах навчального процесу: при вивченні нового матеріалу, при його засвоєнні, а також при перевірці та контролі знань студентів. Найтісніший зв'язок знань і дій є основою формування різних прийомів мислення: суджень, висновків, доказів [1, 2].

Основна частина. Головним завданням підготовки грамотного фахівця є створення в ході навчання міцної бази фундаментальних знань, формування професійних навичок і вмінь. Вивчення аналітичної хімії на другому курсі навчання є підготовкою студентів до свідомого сприйняття профільних дис-

() І. Б. Івануса, М. М. Михалків, А. Є. Демид циплін - фармацевтичної хімії, технології, фармакології, фармакогнозії, токсикологічної хімії.

Аналітична хімія - наука експериментальна, однак, щоб у майбутньому провізор-аналітик міг успішно розвивати нові напрямки і самостійно вирішувати практичні завдання, він повинен глибоко засвоїти теоретичні основи сучасних методів аналізу. Цьому, без сумніву, сприяє розв’язок задач, які стосуються теорії та практики різних розділів аналітичної хімії $[3,4]$.

Неорганічні і органічні лікарські засоби широко застосовуються в медичній практиці. Щоб стандартизувати такі лікарські засоби, необхідно вміти провести певні теоретичні розрахунки. Після цього провізору потрібно вміти визначати якісний склад, кількісний вміст будь-якого засобу, що містить компоненти неорганічної і органічної природи. Наприклад, ізотонічна концентрація прописаної лікарської речовини не завжди вказується в рецепті. У цьому випадку провізор-технолог повинен розрахувати ізотонічну концентрацію, застосовуючи метод із використанням ізотонічних еквівалентів за натрієм хлоридом. Тому при стандартизації лікарських форм майбутній провізор проводить певні 
розрахунки, робить висновки, використовуючи знання, отримані при вивченні аналітичної хімії [5].

Аналітична хімія поділяється на три основні розділи: якісний аналіз, класичні методи аналізу та фізико-хімічні методи аналізу. Кожен з цих розділів містить розрахункові задачі. Вивчення даної дисципліни розпочинається з якісного аналізу, в якому розглядаються чотири види рівноваг: протолітична, гетерогенна, окисно-відновна та комплексоутворення. Кожна з цих рівноваг має свої константи (термодинамічні, реальні та умовні) й основні поняття (рН, розчинність, рівняння Нернста), які в подальшому будуть теоретичним підгрунтям для вивчення основ класичних та фізико-хімічних методів аналізу. Ці розділи містять найбільшу кількість задач.

Зокрема, при вивченні теми “Кислотно-основне титрування” задачі базуються на розрахунках точної наважки стандартних речовин, об’ємів концентрованих розчинів кислот для приготування титрантів та їх стандартизації. А також певний відсоток займають задачі на розрахунок вмісту основного компонента (діючої речовини) за результатами прямого, непрямого (замісникового), зворотного (за залишком) титрування.

Для вибору тих чи інших індикаторів у різних титриметричних методах аналізу, в тому числі й в протолітометрії, студент проводить розрахунки індикаторних похибок та побудову кривих титрування. Наприклад, якщо індикаторна похибка велика, то даний індикатор не може бути використаний в аналізі.

Осаджувальне титрування - метод титриметричного аналізу, який базується на застосуванні титрантів, що утворюють з визначуваною речовиною малорозчинні сполуки. Цей метод є фармакопейним. 3 усіх методів осаджувального титрування найбільш поширений - аргентометрія. При вивченні даного розділу студенти розв’язують задачі на розрахунок вмісту діючої речовини в лікарських формах як органічної, так і неорганічної природи, зокрема таких, як $\mathrm{NaCl}, \mathrm{NaBr}, \mathrm{KBr}, \mathrm{NaI}, \mathrm{KI}$, ефедрину гідрохлориду, галогенпохідних органічних речовин - бромізовалу, карбромалу, бромкамфори, для визначення вмісту срібла в препаратах: протаргол, коларгол, срібла нітрату.

Ще одним з фармакопейних методів аналізу є комплексонометрія. Цей метод експресний, точний і застосовується в аналізі субстанцій і лікарських засобів. Під час вивчення теми “Комплексиметричне титрування” студенти працюють над задачами на визначення вмісту магнію, кальцію, цинку, плюмбуму, вісмуту у лікарських засобах - прямим титруванням, а алюміній - методом зворотного титрування. А також проводять розрахунки комплексонометричного визначення маси та вмісту не лише катіонів металів, але й аніонів, застосовуючи формули розрахунку маси за результатами непрямого (замісникового) і зворотного титрування у поєднанні з методом осадження.

Знання основних положень і закономірностей методів редоксиметрії $є$ важливою частиною в аналітичній освіті провізора. При розв’язуванні задач з окисно-відновного титрування студенти повинні володіти формулами для обчислення молярної маси, титру, титру по визначуваній речовині, масової частки, масово-об’ємної частки, електрорушійної сили, стандартного окисно-відновного потенціалу, який розраховують по рівнянню Нернста - Петерса. Це необхідно враховувати при розрахунках вмісту $\mathrm{H}_{2} \mathrm{O}_{2}$, заліза, натрій нітриту, карбонових кислот, сполук з гідразогрупами $\mathrm{R}-\mathrm{NH}-\mathrm{NH}-\mathrm{R}$ тощо.

Для забезпечення точності визначення і економії витрат реактивів провізору-аналітику потрібно вміти проводити попередні розрахунки маси (об’єму) лікарської форми, потрібні для аналізу, величини розведення, титру, коефіцієнтів перерахунку, теоретичного об’єму титранту, оцінювати результати аналізу і робити висновки.

Отже, запропоновані при контролі знань і умінь розрахункові задачі вимагають самостійного пошуку шляхів і варіантів їі вирішення.

Важливе значення мають розрахунки в гравіметричному аналізі. Студент повинен вміти розраховувати масу наважки досліджуваного об’єкта в залежності від осаджувальної форми (аморфна чи кристалічна). Наступним етапом аналізу є вибір осаджувача та розрахунок його кількості, необхідного для повного переведення визначуваного іона в осад. В подальшому цей осад промивають відповідним розчином, кількість промивань студент повинен вміти розрахувати. По закінченню проведення дослідження треба провести розрахунок вмісту визначуваної речовини в досліджуваному об’єкті.

При вивченні фізико-хімічних методів аналізу (потенціометрія, потенціометричне визначення $\mathrm{pH}$, хроматографія) через нестачу приладового забезпечення виникає необхідність колективного виконання розрахункових задач. При цьому формується вміння студента працювати в колективі.

Тема “Оптичні методи аналізу” вимагає від студента вміти розраховувати коефіцієнт пропускання, 
концентрацію розчину через оптичну густину розчину або показник заломлення, а також розраховувати значення питомих або молярних коефіцієнтів поглинання у перерахунку на катіон відповідного металу. Обов' язково звертається увага на розв'язок задач спектрофотометричних визначень вмісту левоміцетину, рибофлавіну, стрептоциду в таблетках, визначення вмісту вітаміну $\mathrm{B}_{12}$ в ін'єкційних розчинах, визначення вмісту суми флавоноїдів в таблетках флавіну. Після обрахунків кожної задачі студенти роблять висновок про доброякісність препарату.

Рефрактометричні розрахунки майбутні фахівці використають на практиці для кількісного визначення концентрації речовин водних та неводних розчинів, органічних та мінеральних кислот, солей, концентрації етилового спирту, гліцеролу, для визначення вмісту білка в крові, а також для ідентифікації речовини, для кількісного визначення одно-, дво- та багатокомпонентних сумішей, якості розчинів речовин та термінів їх зберігання.

Сучасні лікарські засоби здебільшого є багатокомпонентними. На допомогу провізору-аналітику приходить багатохвильова спектрофотометрія, яка дає змогу провести визначення двох-трьох компонентів з однієї наважки препарату. Тому студенти вчаться розраховувати концентрації, масові частки, вмісти діючих речовин в одній таблетці багатокомпонентних систем. Теж велика увага приділяється розв’язку задач на застосування диференціальної спектрофотометрії, оскільки провізору-аналітику доводиться аналізувати висококонцентровані розчини або визначати вміст речовин у присутності забарвлених розчинів з високою оптичною густиною.

При вивченні теми “Електрохімічні методи аналізу” звертається основна увага на розв’язок задач за результатами потенціометричного титрування. Студенти будують інтегральну та

\section{Список літератури}

1. Електронне джерело: розрахункові задачі [Електронний ресурс]. - Режим доступу до інформації: http://www. zhu.edu.ua/mk_school/pluginfile.php/9798/mod_resource/ content/5/\%D0\%9B\%D0\%B5\%D0\%BA\%D1\%86\%D1\% 96\%D1\%8F\%203.pdf.

2. Теоретичні основи та способи розв’язання задач 3 аналітичної хімії / [ О. А. Бугаєвський, А. В. Дрозд, Л. П. Логінова та ін.]. - Харків : ХНУ, 2003. - 320 с.

3. Сучасна аналітична хімія: збірник задач, тестів i запитань з хімічних методів аналізу : навч. посіб. / за диференціальну криві титрування і розраховують вміст речовин у досліджуваному розчині.

Останнім часом із підвищенням вимог до якості лікарських засобів обов'язковими стали методи газової та високоефективної рідинної хроматографії в аналізі субстанцій і готових лікарських форм. Тому на занятті “Хроматографічні методи аналізу” студенти розв’ язують задачі на кількісне визначення домішки з використанням розчину порівняння 3 відомою концентрацією домішки, звертається увага на метод внутрішньої нормалізації, на метод порівняння з розведеним розчином основної речовини, а також на метод стандартних добавок для підвищення точності. Засвоєні знання із даної теми студенти застосують у подальшій практиці для проведення ідентифікації інгредієнтів в складних лікарських препаратах за допомогою різних видів хроматографії.

Отже, розв’язування задач дозволяє студентам закріпити знання, практично застосувати теоретичний матеріал на практиці, сприяє залученню їх до самостійної роботи з використанням не тільки підручників, але й додаткової літератури.

Як показує практика, розв’язування розрахункових задач є ефективним і поетапним формуванням і розвитком умінь студентів. Спочатку розбирається зразок задачі, форма запису, потім розв'язуються аналогічні та обернені задачі. Коли студенти навчилися розв’язувати типові задачі, починається етап розвитку вмінь, який реалізується шляхом розв’язування складніших та комбінованих задач.

Висновок. Отже, розв'язування розрахункових задач є невід’ ємною частиною практичного заняття при вивченні аналітичної хімії на фармацевтичному факультеті. Це дозволяє краще зрозуміти основні методи та прийоми хімічного аналізу, а також набути комплексних хімічних знань, необхідних для успішного вивчення фахових дисциплін.

заг. ред. Ф. О. Чмиленко. - Д. : Вид-во Дніпропетр. нац. ун-ту, 2008. - 440 с.

4. Чмиленко Ф. О. Сучасна аналітична хімія: електроаналітичні методи : навч. посіб. / Ф. О. Чмиленко, I. В. Коробова. - Д. : Вид-во ДНУ, 2010. - 280 с.

5. Фармацевтическая химия : учеб. пособие / под ред. Л. П. Арзамасцева. - М. : ГЭОТАР-МЕД, 2004. 640 c.

Отримано 25.09.15 